\title{
Knowledge, Attitude and Practice towards COVID-19 among Undergraduate Students in Nepal
}

\author{
Esther Budha Magar', Khushbu Deo² \\ ${ }^{1}$ Research Officer, Consortium for Land Research and Policy Dialogue, Lalitpur, ${ }^{2}$ Lecturer, Kantipur Academy of Health \\ Science, Kathmandu, Nepal
}

Background: Nepal is a landlocked country standing highly vulnerable to unfolding pandemic. As per a UNDP survey in May, three in five employees had lost their job during COVID-19 and most of them were youths. During the first 74 days of lockdown, 16 people committed suicide per day (total 1227 cases). Hence, the main objective of the study was to assess knowledge, attitude, and practice toward COVID-19 in undergraduate students of Nepal. Aims and Objectives: This study aims to assess the knowledge, attitude, and practice among undergraduates of Nepal. Materials and Methods: This study is a cross-sectional study conducted among undergraduates residing in Nepal through online Google Forms for the conduction of online survey using purposive sampling technique. The participants were called through social media and the process about the use of Google Forms was explained by the researcher. The questionnaires were taken from open-access pre-published article. Univariate and bivariate analyses were applied for assessing knowledge, attitude, and practice and their association with independent variables. Results: In this study, among the 120 respondent who had agreed to take part in the research study, the overall knowledge level was found to be high toward COVID-19 among Nepalese undergraduates (Mean $=0.74, \mathrm{SD}=0.16$ ), Majority of the participants, that is, $92.5 \%$ of participants had positive attitude regarding improved immunity as a measure to protect from COVID-19 and had good practice to prevent COVID-19 (Mean =0.84, SD =0.28). Conclusion: The knowledge was found to be high. Furthermore, optimistic attitude and proactive practice was seen among the undergraduates toward the battle against this pandemic. Contradiction to previous studies, significant association of provincial habitat with attitude towards COVID-19 was found.

Key words: Attitude; Knowledge; Practice; COVID-19; Nepalese undergraduate; KAP; Nepal
Access this article online

Website:

http://nepjol.info/index.php/AJMS DOI: 10.3126/ajms.v13i1.40290

E-ISSN: 2091-0576

P-ISSN: 2467-9100

Copyright (c) 2022 Asian Journal of Medical Sciences

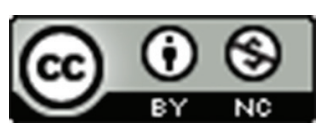

This work is licensed under a Creative Commons Attribution-NonCommercial 4.0 International License.

\section{INTRODUCTION}

In Wuhan city of Hubei Province of China, cases of pneumonia of unknown etiology were detected on December 31, 2019. The WHO China Country Office was informed about the case by Hubei Province. ${ }^{1}$ On January 1, 2020, the WHO set up Incident Management Support Team across three levels of organization. ${ }^{2}$ Myanmar possessed 107\% with 1513 cases, which was followed by $17 \%$ with 7902 cases in Nepal. Hence, SEARO held a regional webinar on intra-action reviews. All SEAR member countries adopted the resolution to fight COVID-19 during the $73^{\text {rd }}$ Regional Committee
Session of the WHO SEAR. ${ }^{3}$ A 32-year-old man who returned back to Nepal from China on January 13, 2020, was the first person to have case of COVID-19 in Nepal. He was ill 6 days before he flew back to Nepal. ${ }^{4}$ This study will create a database regarding knowledge, attitude, and practice of COVID-19 among undergraduates of Nepal aiding valuable insights into public health education and will create a roadmap to upcoming researchers. The study will further shape the planning of governmental authorities and contribute in SDG 3 (good health and well-being). ${ }^{5}$ Thus, the study aims to assess the knowledge, attitude, and practice toward COVID-19 in undergraduate students of Nepal. 


\section{Aims and objectives}

This study aims to assess the knowledge, attitude, and practice among undergraduates of Nepal.

\section{MATERIALS AND METHODS}

This cross-sectional study was carried out among undergraduates' students residing in Nepal from October 2020 to March 2021. A total of 120 undergraduate students (both male and female) were surveyed through online Google Forms using purposive sampling technique. The participants were called through various means of social media and the process about the use of Google Forms was explained by the researcher. The questionnaires were taken from open-access pre-published article. ${ }^{6}$ Pre-testing was done before conducting research and informed consent was taken.

\section{Inclusion criteria}

1. Undergraduate students who were willing to participate in the study were included in the study.

\section{Exclusion criteria}

1. Those who did not give consent to participate.

2. Students studying below bachelor and above bachelor level.

Data were managed in MS Excel and saved in Google Drive. The collected data were entered into Statistical Package for the Social Science (SPSS) version 16. Data were imported into SPSS (version 16) for analysis. The data were presented in mean, median, percentage, and standard deviation, and Kruskal-Walls H-test was used to analyze the data. Data were summarized using frequency distribution tables and graphical methods of presentation of data. Ethical consideration for the conduction of research was taken from Ethical Review Board, Nepal Health Research Council.

\section{RESULTS}

Regarding the knowledge of participants toward COVID-19, based on symptoms (Mean $=0.77, \mathrm{SD}=0.19$ ), awareness (Mean $=0.71, \mathrm{SD}=0.21)$, and prevention $($ Mean $=0.74$, $\mathrm{SD}=0.16)$, the overall knowledge level was found to be high toward COVID-19 among Nepalese undergraduates (Mean $=0.74, \mathrm{SD}=0.16)($ Table 1$)$.

Majority of the respondents (92.5\%) agreed that improved immunity can protect people against the COVID-19 virus. Likewise, $68.3 \%$ of respondents believed that Nepal could win the battle against COVID-19 and half of the respondents, that is, $50.8 \%$ stated that lockdown should be extended to control the COVID-19 (Table 2).
In relation to measured items, the practice toward COVID-19 was found to be good in use of mask/sanitizer/ soap during pandemic whereas the practice was found to be poor $(47.5 \%)$ in the matter of visiting outside of residence to crowded areas (Table 3).

Correlation between sociodemographic characteristics and knowledge (symptom, awareness, and prevention), attitude, and practice toward COVID-19

Significant difference in awareness- and prevention-based knowledge with respect to age group of the respondent was found. The participants within the age of 18-21 years had less mean rank, that is, 49.35 for awareness-based knowledge and 48.31 for prevention-based knowledge as comparison to other participant of different age groups. However, the result was insignificant at 95\% CI (Table 4).

Significant result was observed in attitude with respect to age where mean rank for the participant of age 22-25 is 55.65 which was low in comparison to mean rank of 66.49 and 86.21 of age group 18-21 and 26-29, respectively. The result was significant in practice with respect to gender where the mean rank of male is high, that is, 66.06 and female (56.54), others were comparatively low (Table 5).

\section{DISCUSSION}

Public health education is one of the most effective measures which can prevent and control public health emergencies during pandemic. Spreading knowledge from authorized source of health, developing positive attitude, mitigating panic, and adopting proactive practices may enhance the knowledge, attitude, and practice of undergraduates.

The online cross-sectional survey found that most of the Nepalese undergraduates were well informed about knowledge (symptom, awareness, and prevention based) related to COVID-19 (Mean=0.74, $\mathrm{SD}=0.16$ ).

Regarding the knowledge of COVID-19, knowledge level of Nepalese students $(77.31 \%$ ) was found to be lower as comparison to Chinese undergraduates $(82.3 \%)$, Indian undergraduates $(81.3 \%)$, and higher as comparison to Ethiopian undergraduates (69.6\%) as per the study conducted by Peng et al., ${ }^{7}$ Al-Batanony et al., ${ }^{8}$ and Tadesse et al., ${ }^{9}$ respectively. Regarding the attitude toward COVID-19, Nepalese undergraduates were found to be more optimistic $(70.53 \%)$ than Indian undergraduates $(68.2 \%)$ and Ethiopian undergraduates $(56.6 \%)$ as per a study of Al-Batanony et al., ${ }^{8}$ and Tadesse et al. ${ }^{9}$ In contradiction, it was found that Chinese 
Table 1: Participant's knowledge toward COVID-19 ( $n=120)$

\begin{tabular}{|c|c|c|c|c|c|}
\hline \multirow[t]{2}{*}{ Statements } & \multicolumn{3}{|c|}{ Response } & \multirow[t]{2}{*}{ Mean } & \multirow[t]{2}{*}{ SD } \\
\hline & True & False & I do not know & & \\
\hline \multicolumn{6}{|l|}{ A. Symptom-based knowledge } \\
\hline $\begin{array}{l}\text { The main clinical symptoms of COVID-19 are fever, } \\
\text { fatigue, dry cough, and myalgia }\end{array}$ & $110(91.7 \%)$ & $10(8.3 \%)$ & 0 & 0.92 & 0.28 \\
\hline $\begin{array}{l}\text { Unlike the common cold, stuffy nose, runny nose, and } \\
\text { sneezing are less common in persons infected with the } \\
\text { COVID-19 virus. }\end{array}$ & $65(54.2 \%)$ & $38(31.7 \%)$ & $17(14.2 \%)$ & 0.54 & 0.5 \\
\hline $\begin{array}{l}\text { Not all persons with COVID-19 will develop into severe } \\
\text { cases. Only those who are elderly, have chronic } \\
\text { illnesses, and are obese are more likely to develop into } \\
\text { severe cases. }\end{array}$ & $98(81.7 \%)$ & $10(8.3 \%)$ & $12(10 \%)$ & 0.82 & 0.39 \\
\hline $\begin{array}{l}\text { Persons with COVID-19 cannot infect the virus to others } \\
\text { when a fever is not present. }\end{array}$ & $6(5 \%)$ & $95(79.2)$ & $19(15.8)$ & 0.79 & 0.408 \\
\hline Total symptom-based knowledge & & & & 0.77 & 0.19 \\
\hline \multicolumn{6}{|l|}{ B. Awareness-based knowledge } \\
\hline $\begin{array}{l}\text { Is COVID-19 virus infection a life-threatening health } \\
\text { issue? }\end{array}$ & $91(75.8)$ & $20(16.7 \%)$ & $9(7.5 \%)$ & 0.76 & 0.43 \\
\hline $\begin{array}{l}\text { Multiorgan failure is the cause of death of the patient } \\
\text { suffering from COVID-19 }\end{array}$ & $56(46.7 \%)$ & $36(30 \%)$ & $28(23.3)$ & 0.30 & 0.46 \\
\hline $\begin{array}{l}\text { Eating or contacting wild animals would result in the } \\
\text { infection by the COVID-19 virus }\end{array}$ & $24(20 \%)$ & $72(60 \%)$ & $24(20 \%)$ & 0.60 & 0.49 \\
\hline $\begin{array}{l}\text { The major means of human to human transmission } \\
\text { of COVID-19 is through small droplets when infected } \\
\text { people cough, sneeze, or talk? }\end{array}$ & $112(93.3 \%)$ & 0 & $8(6.7 \%)$ & 0.93 & 0.25 \\
\hline Currently, Nepal is in Stage 2 of COVID-19 infection & $73(60.8 \%)$ & $10(8.3 \%)$ & $37(30 \%)$ & 0.61 & 0.49 \\
\hline $\begin{array}{l}\text { Antimalarial drugs are being used for treating patients } \\
\text { with COVID-19 }\end{array}$ & $55(45.8)$ & $29(24.2 \%)$ & $36(30 \%)$ & 0.24 & 0.43 \\
\hline $\begin{array}{l}\text { Currently, there is no effective cure COVID-19 but early } \\
\text { symptomatic and supportive treatment can help most } \\
\text { patients recover from the infection }\end{array}$ & $110(91.7 \%)$ & $3(2.5 \%)$ & $7(5.8 \%)$ & 0.92 & 0.28 \\
\hline $\begin{array}{l}\text { Does quarantine mean a restriction on the movement of } \\
\text { people that is intended to prevent the spread of disease? }\end{array}$ & $103(85.8 \%)$ & $9(7.5 \%)$ & $8(6.7 \%)$ & 0.86 & 0.35 \\
\hline $\begin{array}{l}\text { Does isolation mean separating a sick individual with a } \\
\text { contagious disease from healthy individual? }\end{array}$ & $107(89.2 \%)$ & $5(4.2 \%)$ & $8(6.7 \%)$ & 0.89 & 0.31 \\
\hline $\begin{array}{l}\text { Does lockdown mean as emergency protocol that } \\
\text { usually prevents people from leaving an area? }\end{array}$ & $98(81.2 \%)$ & $15(12.5 \%)$ & $7(5.8 \%)$ & 0.82 & 0.39 \\
\hline $\begin{array}{l}\text { Does social distancing mean actions intended to slow } \\
\text { the spread of disease by minimizing close contact } \\
\text { between individuals? }\end{array}$ & $108(90 \%)$ & $2(1.7 \%)$ & $10(8.3 \%)$ & 0.90 & 0.301 \\
\hline Total awareness-based knowledge & & & & 0.71 & 0.21 \\
\hline \multicolumn{6}{|l|}{ C. Prevention-based knowledge } \\
\hline $\begin{array}{l}\text { It is not necessary for children and young adults to take } \\
\text { measures to prevent infection by COVID-19 virus. }\end{array}$ & $29(24.2 \%)$ & $84(70 \%)$ & $7(5.8 \%)$ & 0.70 & 0.46 \\
\hline $\begin{array}{l}\text { To prevent the infection by COVID-19, individuals should } \\
\text { avoid going to crowded places such as train stations and } \\
\text { also avoid taking public transportations }\end{array}$ & $111(92.5 \%)$ & $3(2.5 \%)$ & $6(5 \%)$ & 0.92 & 0.26 \\
\hline $\begin{array}{l}\text { Isolation and treatment of people who are infected with } \\
\text { the COVID-19 virus are effective ways to reduce the } \\
\text { spread of the viruses }\end{array}$ & $108(90 \%)$ & $6(5 \%)$ & $6(5 \%)$ & 0.90 & 0.301 \\
\hline $\begin{array}{l}\text { Ordinary residents can wear general masks to prevent } \\
\text { the infection by COVID-19 virus }\end{array}$ & $89(74.1 \%)$ & $18(15 \%)$ & $13(10.8 \%)$ & 0.74 & 0.44 \\
\hline $\begin{array}{l}\text { People who have contact with someone infected with } \\
\text { the COVID-19 virus should be immediately isolated in a } \\
\text { proper place in general, the observation period is } 14 \text { days }\end{array}$ & $112(93.3 \%)$ & $1(0.8 \%)$ & $7(5.8 \%)$ & 0.93 & 0.25 \\
\hline $\begin{array}{l}\text { Does lockdown prevent human-to-human transmission } \\
\text { of COVID-19? }\end{array}$ & $98(81.2 \%)$ & $11(9.2 \%)$ & $11(9.2 \%)$ & 0.82 & 0.389 \\
\hline Total prevention-based knowledge & & & & 0.84 & 0.18 \\
\hline Total knowledge $(A+B+C)$ & & & & 0.74 & 0.16 \\
\hline
\end{tabular}

undergraduates were more optimistic (73.81\%) than Nepalese undergraduates which was a study done by Peng et al. ${ }^{7}$
The practice toward COVID-19, the Chinese undergraduates $(87.9 \%)$ by Peng et al., ${ }^{7}$ and Indian undergraduates $(87.8 \%)$ were found to have high proactive practice as per Al- 
Table 2: Participant's attitude toward COVID-19 ( $n=120)$

\begin{tabular}{|c|c|c|c|}
\hline \multirow[t]{2}{*}{ Statements } & \multicolumn{3}{|c|}{ Response } \\
\hline & Agree & Disagree & I do not know \\
\hline Nepal can win the battle against the COVID-19 virus & $82(68.3 \%)$ & $14(11.7 \%)$ & $24(20 \%)$ \\
\hline $\begin{array}{l}\text { Lockdown period should be extended to control the } \\
\text { COVID-19 }\end{array}$ & $61(50.8 \%)$ & $31(25.8 \%)$ & $28(23.3 \%)$ \\
\hline
\end{tabular}

Highest responses are indicated in bold

Table 3: Participant's practice toward COVID-19 $(n=120)$

\begin{tabular}{|c|c|c|c|c|c|}
\hline \multirow[t]{2}{*}{ Statements } & \multicolumn{3}{|c|}{ Response } & \multirow[t]{2}{*}{ Mean } & \multirow[t]{2}{*}{ SD } \\
\hline & Yes & No & Not always & & \\
\hline $\begin{array}{l}\text { In recent days, have you moved outside of your } \\
\text { residence to any crowded place? }\end{array}$ & $46(38.3 \%)$ & $57(47.5 \%)$ & $17(14.2 \%)$ & 0.48 & 0.50 \\
\hline $\begin{array}{l}\text { Do you use a mask for going outdoors during } \\
\text { COVID-19 pandemic? }\end{array}$ & $116(96.7 \%)$ & $4(3.3 \%)$ & 0 & 0.97 & 0.18 \\
\hline $\begin{array}{l}\text { Do you maintain social distancing during the } \\
\text { COVID-19 pandemic? }\end{array}$ & $104(86.7 \%)$ & $1(0.8 \%)$ & $15(12.5 \%)$ & 0.87 & 0.34 \\
\hline $\begin{array}{l}\text { Do you use sanitizer/soap water to clean your hands } \\
\text { each time after you come from outdoors during the } \\
\text { COVID-19 pandemic? }\end{array}$ & $116(96.7 \%)$ & $1(0.8 \%)$ & $3(2.5 \%)$ & 0.97 & 0.18 \\
\hline $\begin{array}{l}\text { Do you care about improving your immune system } \\
\text { these days? }\end{array}$ & $114(95 \%)$ & $2(1.7 \%)$ & $4(3.3 \%)$ & 0.95 & 0.21 \\
\hline Total practice & & & & 0.84 & 0.28 \\
\hline
\end{tabular}

\begin{tabular}{|c|c|c|c|c|c|c|c|}
\hline $\begin{array}{l}\text { Sociodemographic } \\
\text { characteristics }\end{array}$ & $\begin{array}{l}\text { Frequency } \\
\text { (Percentage) }\end{array}$ & \multicolumn{2}{|c|}{$\begin{array}{c}\text { Symptom-based } \\
\text { knowledge }\end{array}$} & \multicolumn{2}{|c|}{$\begin{array}{l}\text { Awareness-based } \\
\text { knowledge }\end{array}$} & \multicolumn{2}{|c|}{$\begin{array}{l}\text { Prevention-based } \\
\text { knowledge }\end{array}$} \\
\hline \multicolumn{8}{|l|}{ Age } \\
\hline $18-21$ & $34(28.33)$ & 61.71 & 0.22 & 49.35 & $0.072^{*}$ & 48.31 & $0.033^{*}$ \\
\hline $22-25$ & $79(65.83)$ & 61.82 & & 64.92 & & 65.06 & \\
\hline \multicolumn{8}{|l|}{ Gender } \\
\hline Male & $56(46.67)$ & 57.84 & 0.392 & 55.60 & 0.451 & 60.07 & 0.545 \\
\hline Female & $63(52.5)$ & 62.27 & & 64.13 & & 60.32 & \\
\hline Others & $1(0.83)$ & 98 & & 50.50 & & 96 & \\
\hline \multicolumn{8}{|l|}{ Education background } \\
\hline Management & $29(24.17)$ & 61.93 & 0.374 & 58.36 & 0.913 & 58.50 & 0.918 \\
\hline Medical & $5(4.17)$ & 79.60 & & 63.50 & & 58.90 & \\
\hline \multicolumn{8}{|c|}{ Location of permanent resident } \\
\hline Province 1 & $21(17.5)$ & 58.95 & 0.138 & 55.76 & 0.986 & 46.95 & 0.241 \\
\hline Province 2 & $17(14.16)$ & 71.95 & & 59.88 & & 65.62 & \\
\hline Bagmati Province & 62 (51.67) & 53.94 & & 61.65 & & 61.35 & \\
\hline Gandaki Province & $4(3.33)$ & 86.50 & & 69.75 & & 83.88 & \\
\hline Lumbini Province & $5(4.16)$ & 63.80 & & 65 & & 76.60 & \\
\hline Karnali Province & $5(4.16)$ & 61.20 & & 56.20 & & 50.90 & \\
\hline Sudur Paschim Province & $6(5)$ & 82.50 & & 60.67 & & 63.67 & \\
\hline
\end{tabular}

Batanony et al., ${ }^{8}$ as comparison to Nepalese undergraduates $(84.52 \%)$. Ethiopian undergraduates $(65 \%)$ were found to have low proactive practice as comparison to Nepalese undergraduates by Tadesse et al. ${ }^{\text {? }}$

In Nepal, a study revealed that there was a significant association between educational background with awareness-based and prevention-based knowledge whereas insignificant association was observed in case of association of age with awareness-based and prevention-based knowledge which was conducted by Neupane et al. ${ }^{6}$ In contradiction, this study revealed that there is no association between education background and awareness- and prevention-based knowledge but 


\begin{tabular}{|c|c|c|c|c|c|c|c|}
\hline \multirow{2}{*}{$\begin{array}{l}\text { Sociodemographic } \\
\text { characteristics }\end{array}$} & \multirow{2}{*}{$\begin{array}{l}\text { Frequency } \\
\text { (Percentage) }\end{array}$} & \multicolumn{2}{|c|}{ Knowledge } & \multicolumn{2}{|c|}{ Attitude } & \multicolumn{2}{|c|}{ Practice } \\
\hline & & Mean rank & P-value & Mean rank & P-value & Mean rank & P-value \\
\hline \multicolumn{8}{|l|}{ Age } \\
\hline $18-21$ & $34(28.33)$ & 52.76 & 0.22 & 66.49 & $0.026^{*}$ & 50.85 & $0.080^{*}$ \\
\hline $22-25$ & $79(65.83)$ & 64.43 & & 55.65 & & 64 & \\
\hline $26-29$ & $7(5.83)$ & 53.71 & & 86.21 & & 67.86 & \\
\hline \multicolumn{8}{|l|}{ Gender } \\
\hline Male & $56(46.67)$ & 58.04 & 0.53 & 64.58 & 0.183 & 66.06 & $0.033^{*}$ \\
\hline Female & $63(52.5)$ & 62.19 & & 57.60 & & 56.54 & \\
\hline Others & $1(0.83)$ & 91.50 & & 14.50 & & 2 & \\
\hline \multicolumn{8}{|l|}{ Education background } \\
\hline Management & $29(24.17)$ & 56.53 & 0.693 & 64.28 & 0.435 & 68.36 & 0.248 \\
\hline Medical & $5(4.17)$ & 71 & & 44.20 & & 53.20 & \\
\hline Science & $86(71.67)$ & 61.23 & & 60.17 & & 58.27 & \\
\hline Others & 0 & 0 & & 0 & & 0 & \\
\hline \multicolumn{8}{|l|}{ Location of permanent resident } \\
\hline Province 1 & $21(17.5)$ & 57.36 & 0.502 & 64.14 & $0.023^{*}$ & 57.14 & 0.156 \\
\hline Province 2 & $17(14.16)$ & 65.85 & & 69.88 & & 72.47 & \\
\hline Bagmati Province & $62(51.67)$ & 57.10 & & 53.20 & & 56.85 & \\
\hline Gandaki Province & $4(3.33)$ & 90 & & 51.62 & & 64.38 & \\
\hline Lumbini Province & $5(4.16)$ & 70.40 & & 71.60 & & 72.40 & \\
\hline Karnali Province & $5(4.16)$ & 52.50 & & 53 & & 41.20 & \\
\hline Sudur Paschim Province & $6(5)$ & 70.25 & & 99.50 & & 79.58 & \\
\hline
\end{tabular}

significant association between age and awareness- and prevention-based knowledge is prevalent. In addition, significant association between education background with knowledge and attitude toward COVID-19 likewise, insignificant association of age, gender, and permanent resident with attitude and practice was found in the study by Neupane et al. ${ }^{6}$ Whereas, this study reported that there is no significant association between education background with attitude and practice toward COVID-19 rather this study confirmed that there is a significant association of age with attitude and practice, gender with practice toward COVID-19, and permanent resident with attitude toward COVID-19. Medical undergraduates of Baghdad had high level of knowledge toward COVID-19, possessed positive attitude, and performed good practice and proactive behavior of prevention which is comparable with this study of Khalil et al., ${ }^{10}$ and this study conducted in Nepal.

Limitations of the study

A particular limitation of our study was time limit.

\section{CONCLUSION}

The knowledge was found to be high with $77.31 \%$ correct answers from 120 participants. Similarly, 70.53\% of students were optimistic toward the battle against the pandemic. Likewise, $84.52 \%$ indicated a proactive practice with mean and SD to be 0.84 and 0.28 , respectively. In relation to measured items, the practice toward COVID-19 was found to be good in use of mask/sanitizer/soap during pandemic whereas the practice was found to be poor with $47.5 \%$ in the matter of visiting outside of residence to crowded areas. In addition, this study revealed that there is no significant association between education background with attitude and practice toward COVID-19 rather this study confirmed that there is significant association of age with attitude and practice, gender with practice toward COVID-19, and permanent resident with attitude toward COVID-19 amid undergraduates of Nepal.

This research study will be beneficial for providing baseline information that could be helpful for government and health authorities in the awareness campaigns and contribute in conducting further researches particularly targeting Nepalese universities regarding COVID-19.

\section{ACKNOWLEDGMENT}

We are grateful to all the undergraduate students of Nepal who took part in the survey. Without their participation, research would not have been possible.

\section{REFERENCES}

1. World Health Organization. Emergencies Preparedness, Response. Geneva: World Health Organization; 2020. Available from: https://www.who.int. [Last accessed on 2020 Jan 03].

2. World Health Organization. Coronavirus Disease (COVID-19) Pandemic. Geneva: World Health Organization; 2020. Available from: https://www.who.int. [Last accessed on 2020 Jan 04].

3. World Health Organization. Novel Coronavirus-World Health 
Organization. Geneva: World Health Organization; 2020. Available from: https://www.who.int. [Last accessed on 2019 Dec 02].

4. Thompson R. The first 2019 novel Coronavirus case in Nepal. Lancet Infect Dis. 2020;20(3):279-280. https://doi.org/10.1016/S1473-3099(20)30067-0

5. United Nations. \#Envision 2030: 17 Goals to Transform the World for Persons with Disabilities; 2020. https://www.un.org. [Last accessed on 2020 Jan 07].

6. Neupane U, Joshi DR, Joshi PR and Chaudhary S. Knowledge, attitude and practice towards novel Corona virus (COVID-19): A cross-sectional study among social media users in Nepal. Janaki Med Coll J Med Sci. 2020;8(1):14-22. Available from: http://www.nepjol.info/index.php/jmcjms/article/view/31552. [Last accessed on 2020 Jan 07].

7. Peng $\mathrm{Y}$, Pei $\mathrm{C}$, Zheng $\mathrm{Y}$, Wang J, Zhang $\mathrm{K}$, Zheng Z, et al A cross-sectional survey of knowledge, attitude and practice associated with COVID-19 among undergraduate students in China. BMC Public Health. 2020;20(1):1292.

https://doi.org/10.1186/s12889-020-09392-z

8. Al-Batanony MA, Al-Batanony $\mathrm{MA}$ and Mansour AE. A questionnaire-based survey perspective of university students from health and non-health colleges on COVID-19 pandemic: A questionnaire-based survey. Am J Public Health Res. 2020;8(5):176-183. Avilable from: https://www.scholar. google.com/scholar?hl=en\&a; https://www.scholar.google.com/ scholar?hl=en\&as sdt=0\%2c5\&q=a+questionnaire-based + su rvey+perspective+of+university+students+from+health+and+ non-health+colleges+on+covid-19+pandemic\%3a+a+questionnaire-based+survey\&btng=; https://www.researchgate.net/ profile/manal-al-batanony/publication/345161323_perspective of_university_students_from_health_and_non-health_colleges on covid-19 pandemic/links/5f9fceea92851c14bcfc66f9/ perspective-of-university-students-from-health-and-non-healthcolleges-on-covid-19-pandemic.pdf. [Last accessed on 2020 Jan 07].

https://doi.org/10.12691/ajphr-8-5-6

9. Tadesse A, Melese N, Eshetie S, Chane M and Ali A. Knowledge, Attitude, and Practice and Associated Factors Towards COVID-19 among College Students in Amhara Region, Ethiopia; A Cross-Sectional Study; 2020. p. 2-14. Avilable from: https://www.assets.researchsquare.com/fil; https://www.scholar. google.com/scholar?HI=en\&as_sdt=0\%2C5\&q=knowledge $\% 2$ c+attitude $\% 2 c+a n d+$ practice+and+associated+factors+towar ds+covid-19+among+college+students+in+amhara+region $\% 2$ c+ethiopia\%3b+a+cross-sectional+study.\&btng=; https://www. assets.researchsquare.com/files/rs-38099/v1_stamped.pdf. [Last accessed on 2020 Jan 10].

10. Khalil N, Al-Yuzbaki D and Tawfeeq R. COVID-19 knowledge, attitude and practice among medical undergraduate students in Baghdad city. Eur Asian J Biosci. 2020;14(2):4179-4186. Avilable from: https://www.scholar.google.com/scholar?hl=en\&as sdt=0 $\% 2 \mathrm{C} 5 \& \mathrm{q}=$ knowledge $\% 2 \mathrm{C}+$ attitude+and+practice+among + med ical+undergraduate+students+in+baghdad+city\&btnG=; https:// www.ejobios.org/article/covid-19-knowledge-attitude-andpractice-among-medical-undergraduate-students-in-baghdadcity-8063. [Last accessed on 2020 Jan 13].

\section{Authors Contribution:}

EBM - Research article concept, designing, cross-checking of data, definition of intellectual content, data acquisition, data collection, analysis, and manuscript review; KD - Literature review, data collection, analysis, interpretation, and manuscript editing.

\section{Work attributed to:}

Consortium for Land Research and Policy Dialogue and Kantipur Academy of Health Science.

\section{Orcid ID:}

Esther Budha Magar - (D) https://orcid.org/0000-0002-6126-6254

Khushbu Deo - (iD https://orcid.org/0000-0002-6544-8100 